\title{
Drought area of agricultural land using Tasseled Cap Transformation (TCT) method in Ciampel Subdistrict Karawang Regency
}

\author{
Iffa Faliha Dzakiyah ${ }^{1}$ and Ratna Saraswati ${ }^{*}$ \\ ${ }^{1}$ Department of Geography, Faculty of Mathematics and Natural Science, Universitas Indonesia, \\ Depok 16424, Indonesia.
}

\begin{abstract}
Drought is water availability that is far below the water needs for life, agriculture, economic activities, and the environment. The impact of severe drought in Indonesia occurred in 2015 due to the strong El Nino phenomenon and positive IOD. The Regional Disaster Management Agency (BPBD) of Karawang Regency noted that drought in 14 villages spread across three subdistricts in Karawang Regency expanded in 2019. One of them is the Ciampel subdistrict. The purpose of this research is to analyze the drought of agricultural land based on green vegetation, soil organic content, and soil moisture using Tasseled Cap Transformation (TCT) method in Ciampel Subdistrict, Karawang Regency in 2015 and 2019. This research uses Landsat 8 OLI imagery in August 2015, September 2015, July 2019, and September 2019. Agricultural land drought includes three indices, namely the brightness index, wetness index and greenness index. Overlay and scoring three drought parameters to making the map drought of agriculture land with four classes such as normal, moderate, high, and very high drought classes. The results show that the drought occurred in 2015 and 2019, but the dry area is more expansive in 2015 than 2019.
\end{abstract}

\section{Introduction}

Indonesia is an archipelago between the Pacific Ocean and the Indian Ocean and between the Asian Continent and the Australian Continent. Indonesia is an area crossed by the equator. It causes Indonesia has a tropical climate, and the influence of the two oceans causes the positive Indian Ocean Dipole (IOD) phenomenon and El Nino or La Nina [1]. The positive of Indian Ocean Dipole (IOD) and El Nino are strong cause of drought in Indonesia [2]. The strong El Nino phenomenon and positive IOD that occurred simultaneously in 2015 caused severe drought impacts in Indonesia [3]. Drought is a condition of lack of water in an area for a long time due to lack of rainfall [4]. Drought is closely related to water reserves in the ground, both water reserves for land and everyday human needs. Agricultural drought tends to occur on a medium and long-term time scale

\footnotetext{
* Corresponding author: ratna.saraswati@ui.ac.id
} 
and the associated impacts include reduction or failure of crop yields, and ultimately shortages in food demand/supply [5].

The strong El Nino phenomenon occurred in August 2015-March 2016, during the strong El Nino period, atmospheric conditions were divided into two, namely dry months (August-October) and wet months (November-March) [6]. The results of the analysis and predictions from several countries stated in March-November 2019 that El Nino was weak [7]. The Indonesian state experienced drought and losses due to the drought. Even the area is known as the Rice Barn also had drought impacts such as in Karawang Regency. The Disaster Management Agency (BPBD) Karawang Regency noted that the drought in 14 villages spread across three subdistricts in Karawang Regency, such as Ciampel Subdistrict in 2015 and 2019 [8]. Paddy fields affected by drought in Ciampel Subdistrict in 2019 are 355 hectares out of 1131 hectares [9]. Ciampel Subdistrict in 2015 experienced a smaller value of rice production than in 2018, which is 20441 tons and 26741 tons [10; 11$]$.

The drought of agricultural land can be seen from the soil's organic content, soil moisture, and greenness of vegetation [12]. The surface organic matter and soil moisture content are seen from the brightness and wetness index using the Tasseled Cap Transformation (TCT) method developed by [13]. The greenness of vegetation is seen from the vegetation greenness index using the Normalized Difference Vegetation Index (NDVI) method. Research on drought with the TCT method with the title detection of drought potential based on remote sensing and geographic information system in Klaten Regency. The result indicated that the areas with the greatest drought potential are in the southern and central parts of Klaten [14].

The research with the title Detection of drought area using greening index and wetness index in Sukaresmi District, Cianjur Regency, West Java was the drought area during 2013 and 2017 was $8 \%$ of the total Sukaresmi District. The drought area lies in paddy field, Brown Latosol soil type, and an altitude 500-1,000 msl [15]. Then, another research with the title Drought potential of paddy fields using temperature vegetation drought index (TVDI) in Kuningan Regency. The result showed that TVDI is dominated by dry class and there is a weak relationship between two variables, which means that the value of TVDI has no significant effect on rice productivity and the relationship is negative or unidirectional. It means that the higher value of TVDI, the lower value of productivity [16]. This study aims to analyze the drought of agricultural land based on green vegetation, soil organic content, and soil moisture using the TCT method in Ciampel Subdistrict in 2015 and 2019.

\section{Method}

This study used Landsat 8 OLI / TIRS image that was downloaded from USGS. The image used is recording on August 30, 2015; September 11, 2015; July 25, 2019; and September 11,2019 . Besides, this study also used an administrative map of the Ciampel Subdistrict, Karawang Regency obtained from the Geospatial Information Agency (BIG) and a map of Ciampel Subdistrict, Karawang Regency land use obtained from the National Land Agency (BPN).

The variables are: (1) Soil brightness as an indication of drought in agricultural land uses the TCT method with a brightness index; (2) Soil wetness as an indication of drought in agricultural land using the TCT method with wetness index; (3) Greening of vegetation as an indication of the drought of agricultural land using the TCT method with NDVI; (4) Agricultural land is the land use studied in this study. Image data processing in this research uses Landsat 8 OLI / TIRS image data processed through the pre-processing and processing stages. The pre-processing stage is image calibration, correction and image cutting based on the study area, namely Ciampel Subdistrict, Karawang Regency.The processing stage is the 
stage by which the Landsat OLI calculation of the spectral value, which is Brightness index and wet index algorithm created by [13]:

$$
\begin{aligned}
\text { Brightness Index }= & (0.3029 \text { Band2 })+(0.2786 \text { Band } 3)+(0.4733 \text { Band4 })+(0.5599 \text { Band5 }) \\
& +(0.508 \text { Band6 })+(0.1872 \text { Band }) \\
\text { Wetness Index }= & (0.1511 \text { Band2 })+(0.1973 \text { Band3 })+(0.3283 \text { Band4 })+(0.3407 \text { Band } 5) \\
& -(0.07117 \text { Band6 })-(0.4559 \text { Band })
\end{aligned}
$$

The higher brightness index value indicates the drier agricultural land. The lower wetness index value indicates drier agricultural land. The greenness of vegetation is seen from the vegetation greenness index using the Normalized Difference Vegetation Index (NDVI) method. NDVI is an index to determine the density value of vegetation, represented by a value of -1 to 1 . To get the NDVI value, a NIR wave and a Red wave are used. [17].

$$
N D V I=((N I R-R e d)) /((N I R+R e d))
$$

Three parameters are given a score from numbers 1 to 5 . The determination of the scoring is based on the greater the score given, the smaller the effect on drought [12]. The interval in each drought class is done by adding up each score from each parameter. The highest score is then reduced by the lowest score divided by the number of classes used [18]. The highest and lowest scores are 15 and 3. The number of classes used is 4 . So, the interval for each drought class is 3 . Table 1 shows the classification drought of land agricultural.

Table 1. The classification drought of land agricultural

\begin{tabular}{|c|c|}
\hline Scoring & Drought Class \\
\hline $3-5$ & Very dry \\
\hline $6-8$ & Dry \\
\hline $9-11$ & Moderate \\
\hline $12-15$ & Normal \\
\hline
\end{tabular}

After the image is processed using the TCT method, Clip the land use data to separate agricultural land from non-agricultural land. Agricultural land consists of dry fields, irrigated rice fields, and rainfed rice fields. Then, use the Union process between agricultural land dryness data and agricultural land data to obtain agricultural land's dryness level based on land use units on agricultural land. After that, use the Calculate Geometry and Summarize processes to determine the dryness area of agricultural land. Figure 1 shows a map of the Ciampel Subdistrict, Karawang Regency land use obtained from the National Land Agency (BPN). 


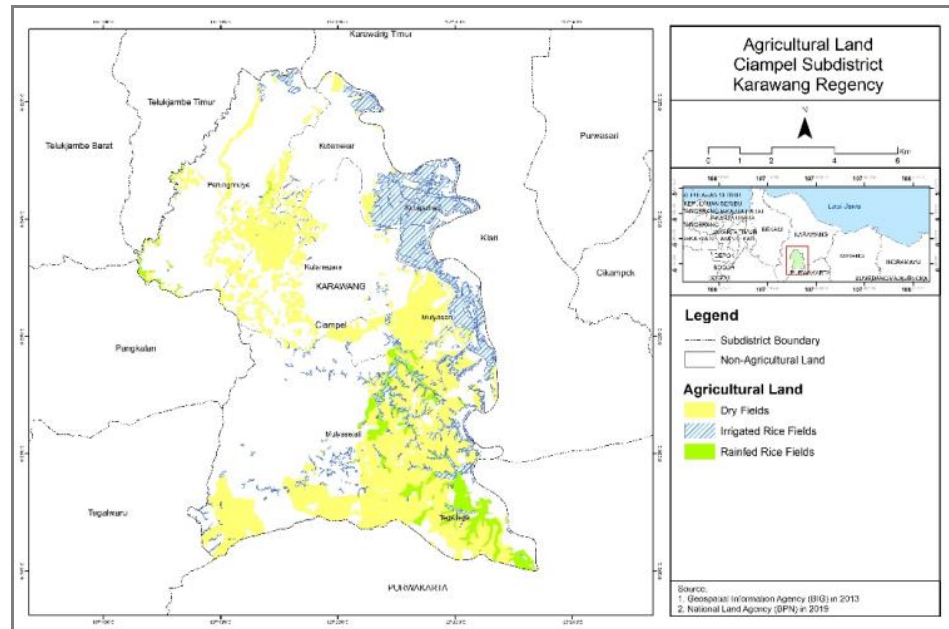

Fig. 1. Agricultural Land in Ciampel Subdistrict, Karawang Regency (Source: Author's Analysis)

\section{Results and discussion}

\subsection{Parameters of drought}

The Tasseled Cap Transformation (TCT) method using three parameters of dryness of agricultural land namely the greenness index (NDVI), the brightness index, and the wetness index, obtained spectral value or digital number (DN) from Landsat 8 OLI/TIRS in August 2015, September 2015, July 2019, and September 2019 with a description of the minimum and maximum values, shows in Table 2.

Table 2. The minimum and maximum NDVI, Brightness Index, and Wetness Index values in Ciampel District.

\begin{tabular}{|c|c|c|c|c|c|c|}
\hline \multirow{2}{*}{$\begin{array}{l}\text { Image } \\
\text { Recording }\end{array}$} & \multicolumn{2}{|l|}{ NDVI } & \multicolumn{2}{|c|}{ Brightness Index } & \multicolumn{2}{|c|}{ Wetness Index } \\
\hline & Minimum & Maximum & Minimum & Maximum & Minimum & Maximum \\
\hline $\begin{array}{l}\text { August } \\
2015\end{array}$ & -0.2305 & 0.7734 & 0.1049 & 1.0480 & -0.1151 & 0.1688 \\
\hline $\begin{array}{l}\text { September } \\
2015\end{array}$ & 0.0444 & 0.5979 & 0.2083 & 1.0249 & -0.0678 & 0.1840 \\
\hline July 2019 & -0.1234 & 0.7542 & 0.0946 & 0.7454 & -0.1040 & 0.1656 \\
\hline $\begin{array}{l}\text { September } \\
2019\end{array}$ & -0.1504 & 0.7292 & 0.1076 & 1.4828 & -0.2828 & 0.1700 \\
\hline
\end{tabular}

Based on Table 2 shows that the minimum value of NDVI is -0.2305 in August 2015. This means that the minimum vegetation condition reached in August 2015. In August 2015, the highest value was 0.7734 , meaning that it reaches the maximum green condition of vegetation in August 2015. The maximum value of the brightness index is 1.4828 in September 2019. It has the lowest organic content value in September 2019 compared to other months. The minimum value of the wetness index is -0.2828 in September 2019. It has the lowest soil wetness value in September 2019 compared to other months.

The map of three parameters of dryness of agricultural land shows in Fig. 2. Fig. 2. (a), the individual value that is very low and low in an area indicated the high drought 
occurrence. The map showed from the NDVI level, drought dominated in eastern of Ciampel Subdistrict. Fig. 2. (b), the brightness index map shows that areas with very high and high brightness index levels dominated in the northeast of the Ciampel Subdistrict. Brightness index values that are very high and high in an area indicated the high occurrence of drought. Fig. 2. (c), the wetness index map shows that the lower level of wetness index indicated that area occurrence of drought. The map shows from Wetness index level, drought dominated in Eastern of Ciampel Subdistrict.



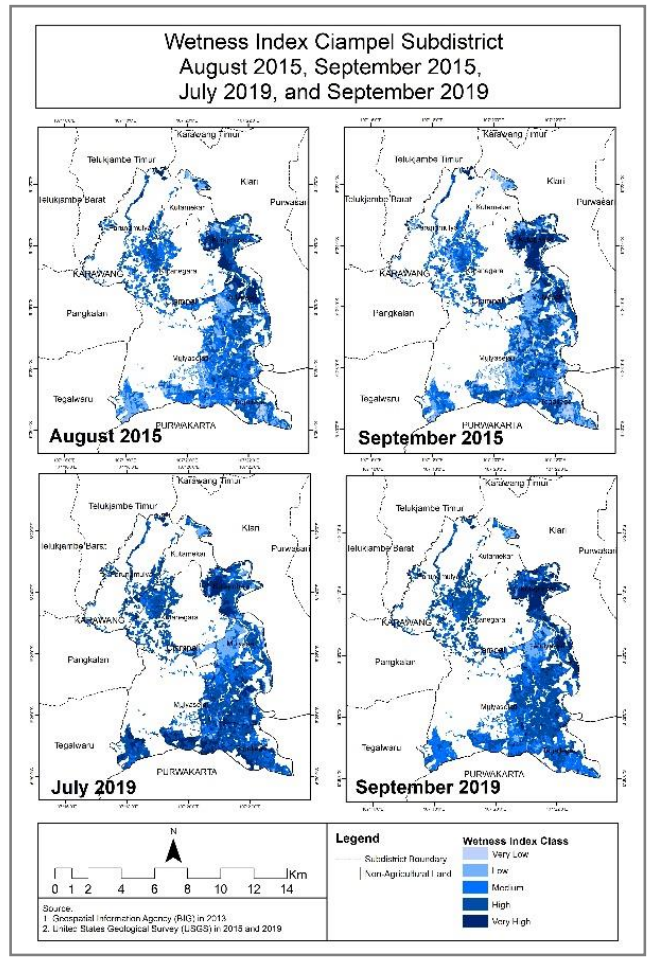

Fig. 2. (a) NDVI; (b) Brightness Index; (c) Wetness Index in Ciampel Subdistrict (Source: Author's Analysis)

\subsection{Drought of agricultural land}

Based on image processing data results using the index of greenness, brightness, and wetness, produce a map of the drought of agricultural land. A map of the agricultural land drought using the TCT method in Ciampel Subdistrict in August 2015, September 2015, July 2019, September 2019, can be seen in Fig. 2. The area of the agricultural land drought using the TCT method in Ciampel Subdistrict in August 2015, September 2015, July 2019, and September 2019 can be seen in Table. 3. 




Fig. 3. Map of TCT in August 2015, September 2015, July 2019, and September 2019 (Source: Author's Analysis)

In Fig. 3, the map of the drought area of agricultural land in August 2015 shows that dry areas dominated in the eastern of Ciampel Subdistrict and normal areas dominated in the northeast of Ciampel Subdistrict. The map of the drought area of agricultural land in the Ciampel Subdistrict in September 2015 shows that dry areas dominated in the eastern of Ciampel Subdistrict and normal areas dominated northeast Ciampel Subdistrict. The map of the dryness of agricultural land in July 2019 shows that dry areas dominated in the eastern of Ciampel Subdistrict and normal areas dominated in the northeast of the Ciampel Subdistrict. The map of the drought area of agricultural land in September 2019 shows that dry areas dominated in the eastern of Ciampel Subdistrict and normal areas dominated northeast of the Ciampel Subdistrict. Therefore, the dry area is dominated in the eastern of Ciampel Subdistrict, which occurred in August 2015, September 2015, July 2019, and September 2019, and the normal area is dominated in the northeast of Ciampel Subdistrict, which occurred in August 2015, September 2015, July 2019, and September 2019. 
Table 3. Area of the drought of agricultural land in August 2015, September 2015, July 2019, and September 2019

\begin{tabular}{|c|c|c|c|c|c|c|c|c|}
\hline \multirow{2}{*}{$\begin{array}{l}\text { Drought } \\
\text { Class }\end{array}$} & \multicolumn{2}{|c|}{ August 2015} & \multicolumn{2}{|c|}{ September 2015} & \multicolumn{2}{|c|}{ July 2019} & \multicolumn{2}{|c|}{ September 2019} \\
\hline & $\begin{array}{l}\text { Area } \\
\left(\mathrm{km}^{2}\right)\end{array}$ & $\begin{array}{l}\text { Percent } \\
\text { age } \\
(\%)\end{array}$ & $\begin{array}{l}\text { Area } \\
\left(\mathrm{km}^{2}\right)\end{array}$ & $\begin{array}{l}\text { Percent } \\
\text { age } \\
(\%)\end{array}$ & $\begin{array}{l}\text { Area } \\
\left(\mathrm{km}^{2}\right)\end{array}$ & $\begin{array}{l}\text { Percent } \\
\text { age } \\
(\%)\end{array}$ & $\begin{array}{l}\text { Area } \\
\left(\mathrm{km}^{2}\right)\end{array}$ & $\begin{array}{l}\text { Percent } \\
\text { age } \\
(\%)\end{array}$ \\
\hline Very Dry & 1.04 & 2.40 & 1.40 & 3.23 & 1.27 & 2.91 & 0.73 & 1.68 \\
\hline Dry & 10.65 & 24.50 & 11.92 & 27.41 & 7.87 & 18.10 & 8.48 & 19.51 \\
\hline Moderate & 20.04 & 46.10 & 19.46 & 44.77 & 17.22 & 39.61 & 19.31 & 44.42 \\
\hline Normal & 11.74 & 27.00 & 10.69 & 24.59 & 17.12 & 39.38 & 14.95 & 34.39 \\
\hline
\end{tabular}

Table 3 shows that the highest dry class area is $1.4 \mathrm{~km} 2$ or $2.4 \%$ in September 2015. The highest area of the dry class is $11.92 \mathrm{~km} 2$ or $27.41 \%$ in September 2015. The highest area of the moderate class is $19.46 \mathrm{~km} 2$ or $44.77 \%$ in September 2015. Besides, the highest area of the normal class is $17.12 \mathrm{~km} 2$ or $39.38 \%$ in July 2019. The dry area (very dry, dry, and moderate) in August 2015 is $31.73 \mathrm{~km} 2$; September 2015 is $32.78 \mathrm{~km} 2$; July 2019 is $26.35 \mathrm{~km} 2$; September 2019 is $28.52 \mathrm{~km} 2$. The highest dry area (very dry, dry, and moderate) is in September 2015, and the highest of the normal area is in July 2019.

Overlay results between a map of the drought of agricultural land and the map of agricultural land, producing areas of agricultural land drought based on the unit of analysis. Table 4 shows the drought of agricultural land based on the land-use units in August 2015, September 2015, July 2019, and September 2019.

Table 4. Area of the drought of agricultural land based on the land-use units in August 2015, September 2015, July 2019, and September 2019

\begin{tabular}{|c|c|c|c|c|c|c|c|c|c|}
\hline \multirow[b]{2}{*}{$\begin{array}{c}\text { Agricult } \\
\text { ural } \\
\text { Land }\end{array}$} & \multirow[b]{2}{*}{$\begin{array}{c}\text { Drought } \\
\text { Class }\end{array}$} & \multicolumn{2}{|c|}{ August 2015} & \multicolumn{2}{|c|}{ September 2015} & \multicolumn{2}{|c|}{ July 2019} & \multicolumn{2}{|c|}{ September 2019} \\
\hline & & $\begin{array}{l}\text { Area } \\
\left(\mathrm{km}^{2}\right)\end{array}$ & $\begin{array}{l}\text { Perce } \\
\text { ntage } \\
(\%)\end{array}$ & $\begin{array}{l}\text { Area } \\
\left(\mathrm{km}^{2}\right)\end{array}$ & $\begin{array}{l}\text { Percen } \\
\text { tage } \\
(\%)\end{array}$ & $\begin{array}{l}\text { Area } \\
\left(\mathrm{km}^{2}\right)\end{array}$ & $\begin{array}{l}\text { Percen } \\
\text { tage } \\
(\%)\end{array}$ & $\begin{array}{l}\text { Area } \\
\left(\mathrm{km}^{2}\right)\end{array}$ & $\begin{array}{l}\text { Perce } \\
\text { ntage } \\
(\%)\end{array}$ \\
\hline \multirow{4}{*}{$\begin{array}{l}\text { Dry } \\
\text { Fields }\end{array}$} & Very Dry & 0.75 & 2.56 & 1.01 & 3.47 & 0.97 & 3.32 & 0.63 & 2.17 \\
\hline & Dry & 6.72 & 23.02 & 7.75 & 26.54 & 4.14 & 14.17 & 5.12 & 17.52 \\
\hline & Moderate & 13.75 & 47.08 & 14.04 & 48.09 & 10.76 & 36.84 & 13.67 & 46.82 \\
\hline & Normal & 7.98 & 27.34 & 6.40 & 21.91 & 13.34 & 45.67 & 9.78 & 33.49 \\
\hline \multirow{4}{*}{$\begin{array}{l}\text { Irrigated } \\
\text { Rice } \\
\text { Fields }\end{array}$} & Very Dry & 0.24 & 2.14 & 0.29 & 2.67 & 0.28 & 2.58 & 0.09 & 0.82 \\
\hline & Dry & 2.79 & 25.36 & 2.80 & 25.37 & 2.81 & 25.53 & 2.37 & 21.55 \\
\hline & Moderate & 4.65 & 42.21 & 3.97 & 36.06 & 4.99 & 45.31 & 4.11 & 37.25 \\
\hline & Normal & 3.34 & 30.30 & 3.96 & 35.90 & 2.93 & 26.59 & 4.45 & 40.39 \\
\hline \multirow{4}{*}{$\begin{array}{l}\text { Rainfed } \\
\text { Rice } \\
\text { Fields }\end{array}$} & Very Dry & 0.06 & 1.77 & 0.10 & 2.99 & 0.01 & 0.37 & 0.007 & 0.22 \\
\hline & Dry & 1.13 & 34.87 & 1.37 & 42.19 & 0.92 & 28.19 & 0.99 & 30.49 \\
\hline & Moderate & 1.64 & 50.58 & 1.44 & 44.46 & 1.47 & 45.24 & 1.53 & 47.22 \\
\hline & Normal & 0.42 & 12.78 & 0.34 & 10.36 & 0.85 & 26.20 & 0.72 & 22.07 \\
\hline
\end{tabular}

The drought area of agricultural land using the TCT method in August 2015 has the highest percentage in dry areas, namely rainfed rice fields at $36.64 \%$ and the highest percentage in normal areas, namely irrigated rice fields at $30.30 \%$. The drought area of agricultural land using the TCT method in September 2015 has the highest percentage in dry areas, namely rainfed rice fields at $45.18 \%$ and the highest percentage in normal areas, 
namely irrigated rice fields at $35.90 \%$. The drought area of agricultural land using the TCT method in July 2019 has the highest percentage in dry areas, namely rainfed rice fields at $28.56 \%$ and the highest percentage in normal areas, namely dry fields at $45.67 \%$. The TCT map in September 2019 has the highest percentage in dry areas, namely rainfed rice fields at $30.71 \%$ and the highest percentage in normal areas, namely irrigated rice fields at $40.39 \%$.

\section{Conclusion}

Based on the result and discussion, drought is based on green vegetation, soil organic content, and soil moisture using Tasseled Cap Transformation (TCT), which focuses on the land surface. The dry area dominated in the eastern of the Ciampel Subdistrict, and the normal area dominated on the northeast of the Ciampel Subdistrict. The cause of the dominance of the spread of dryness in agricultural land is land surface and land use units. The highest percentage is in dry areas, namely rainfed rice fields that occurred in August 2015, September 2015, July 2019, and September 2019. The highest percentage is in normal areas, namely irrigated rice fields that occurred in August 2015, September 2015, and September 2019. The highest area of the very dry, dry, and moderate class is in September 2015. The highest area of the normal class is in July 2019. Meanwhile, the highest of the dry areas (very dry, dry, and moderate) is $32.78 \mathrm{~km}^{2}$ in September 2015. Therefore, agricultural land's drought area shows that the dry area is more expansive in 2015 than in 2019.

\section{Acknowledgements}

The author would like to thank the Directorate of Research and Community Service (DRPM) Universitas Indonesia, which has supported this research in Publikasi Terindeks Internasional (PUTI) SAINTEKES UI Year 2020 with contract number NKB2402/UN2.RST/HKP.05.00/2020

\section{References}

1. I. Iskandar, There are "Two Poles" in the Indian Ocean, Lembaga Ilmu Pengetahuan Indonesia (2008)

2. Liong TH, Siregar P, Bannu. The Role of Grouping in Drought Predictions in Indonesia. Proceedings of the 2002 National Weather and Climate Prediction Meeting; Development and Application of Weather and Climate Prediction Techniques, J. of Computer Science 1, 23-49 (2003)

3. National Institute of Aeronautics and Space (LAPAN). Fenomena Iklim: Fenomena El Nino Ekstrem di Indonesia (2015). Available from: http://www.lapan.go.id/

4. Hadiyanto S. Pola Tingkat Kerawanan Kekeringan di Jawa Tengah. Depok: Department of Geography FMIPA UI (2014)

5. West H, Quinn N, Horswell M. Remote sensing for drought monitoring \& impact assessment : Progress, past challenges and future opportunities. Remote Sens Environ [Internet], 232 (2018). Available from: https://doi.org/10.1016/j.rse.2019.111291

6. Athoillah, Ibnu. Sibarani, R.M. Doloksaribu, D.E. Analisis Spasial Pengaruh Kejadian El Nino Kuat Tahun 2015 dan La Nina Lemah Tahun 2016 Terhadap Kelembapan, Angin dan Curah Hujan di Indonesia. Jurnal Sains \& Teknologi Modifikasi Cuaca 18, 33 - 41 (2017) 
7. Ministry of Agriculture. El Nino and La-Nina Analysis and Prediction of 2019 (2019). Available from: http://sipetani.pertanian.go.id/

8. Regional Disaster Management Agency (BPBD). Regional Disaster Management Agency Karawang Regency (2019). Available form: http://www.karawangkab.go.id/

9. Unit Pelaksanan Teknis Dinas (UPTD) Pengelolaan Pertanian Kecamatan Ciampel. Program Penyuluhan Pertanian Kecamatan Ciampel Tahun 2020. Karawang: Unit Pelaksanan Teknis Dinas (UPTD) Pengelolaan Pertanian Kecamatan Ciampel (2019).

10. Badan Pusat Statistik (BPS). Kabupaten Karawang Dalam Angka 2016. Karawang. Badan Pusat Statistik. Indonesia (2016)

11. Badan Pusat Statistik (BPS). Kabupaten Karawang Dalam Angka 2019. Karawang: Badan Pusat Statistik. Indonesia (2019)

12. Raharjo, Puguh Dwi. Teknik Pengindraan Jauh dan Sistem Informasi Geografis Untuk Identifikasi Potensi Kekeringan. Jawa Tengah: Balai Informasi dan Konservasi Kebumian, Karangsambung, Lembaga Ilmu Pengetahuan Indonesia 14, 97-105 (2010)

13. Hasan A B M, Zhang L, Shuai T and Tong Q. Derivation of a Tasselled Cap Transformation Based on Landsat 8 At-Satellite Reflectance. Remote Sensing Letters 5:5, 423-431 (2014)

14. Jamil DH, Tjahjono H, Parman S. Deteksi Potensi Kekeringan Berbasis Pengindraan Jauh dan Sistem Informasi Geografis di Kabupaten Klaten, 2(2):30-7 (2013)

15. Anugerah, M.M., Wibowo A., Kusratmoko E. Detection of drought area using greening index and wetness index in Sukaresmi Subdistrict, Regency Cianjur, West java. Padjadjaran Earth Dialogues, International Symposium on Geographical Issues. IOP Conference Series: Earth and Environmental Science 311 (2019)

16. Putri DN, Saraswati R, Ash-shidiq IP. Drought Potential of Paddy Fields using Temperature Vegetation Dryness Index in Kuningan Regency, 9(201 9):8-11 (2019)

17. Ardiansyah. Remote Sensing Image Processing Using ENVI 5.1 and ENVI LIDAR. Jakarta: PT Labsig Inderaja Islim (2015)

18. Rasjiddin AI, Sobirin S, Waryono T. The potential of agriculture is drought according to the brightness and wetness index on Kebumen district (2017) Availabe from: https://doi.org/10.1088/1755-1315/481/1/012060 